\title{
Susceptibility of Eucalyptus spp. to an induced infestation of red gum lerp psyllid Glycaspis brimblecombei Moore (Hemiptera: Psyllidae) in Santiago, Chile
}

\author{
Amanda Huerta ${ }^{1}$, Miguel Faúndez ${ }^{1}$, and Jaime E. Araya ${ }^{2}$ \\ 'Departamento de Silvicultura, Facultad de Ciencias Forestales y Conservación de la Naturaleza, \\ Universidad de Chile. Casilla 9206 Santiago, Chile. \\ ${ }^{2}$ Departamento de Sanidad Vegetal, Facultad de Ciencias Agronómicas, Casilla 1004, Santiago, Chile, \\ Universidad de Chile.
}

\begin{abstract}
A. Huerta, M. Faúndez, and J. E. Araya. 2010. Susceptibility of Eucalyptus spp. to an induced infestation of red gum lerp psyllid Glycaspis brimblecombei Moore (Hemiptera: Psyllidae) in Santiago, Chile. Cien. Inv. Agr. 37(2): 27-33. To determine the susceptibility of important species of eucalypt trees in Chile to Glycaspis brimblecombei Moore (Hemiptera: Psyllidae), an insect that was detected on Eucalyptus camaldulensis Dehn. in 2002 in Santiago, which causes defoliation of trees affected, and even their death in severe infestations, a field evaluation of an induced infestation was performed in 2004 of one-year-old plants of E. camaldulensis, E. nitens Deane \& Maiden, and E. globulus Labill. Growths of infested plants were compared with uninfested controls, using destructive sampling at 15, 30, 45, and 60 days. Also, observations were made regarding the duration of the development stages of the insect during two generations. The only species that was susceptible to the psyllid was E. camaldulensis, while it did not develop on E. nitens and E. globulus. The plants of $E$. camaldulensis infested with adults of $G$. brimblecombei had small and not significant reductions in plant height, diameter at trunk base, and foliar area, in comparison with control plants after two months. In the Santiago bioclimatic zone, this insect completed the first generation in 30 days (February-March), and the second in 36 days (March-April).
\end{abstract}

Key words: Eucalyptus camaldulensis, Eucalyptus globulus, Eucalyptus nitens, Glycaspis brimblecombei, red gum lerp psyllid.

\section{Introduction}

Chile has been invaded in recent years by foreign pests of great impact on eucalypt trees (Poisson and Sandoval, 1998; Beéche, 1999; Meza and Baldini, 2001), among which is the red gum lerp psyllid Glycaspis brimblecombei
Moore (Hemiptera: Psyllidae), a species that was detected in 2001 in the neighbourhood of the International Airport of Santiago, on Eucalyptus camaldulensis Dehn (Sandoval and Rothmann, 2002). According to Ide et al. (2006), this insect is distributed from the regions of Coquimbo (north-central) through La Araucanía (south-central).

In the US and Mexico, this insect native to Australia (Garrison, 2001) causes high mortality of
Received October 07, 2009. Accepted November 01, 2009. Corresponding author: ahuertaf@gmail.com 
eucalypt trees, affecting severely the forestry sector (Brennan et al., 1999; Macias, 2001). The main damage of this pest is the weakening of the trees by suction of sap, which in severe infestations reduces the foliage and causes growth losses, the death of shoots and branches, and in extreme cases, the death of plants. The infestation is detected easily by the presence of lerps, white cones that protect the nymphs, together with honeydew that favors the development of black fungi (sooty mold) on the leaves, reducing photosynthesis (Paine et al., 2006). A high density of $G$. brimblecombei causes severe loss of foliage that extremely weakens the affected tree, and favors damage by other insects, like cerambycids Phoracantha recurva Newman or P. semipunctata Fabr. (Garrison, 2001; Paine et al., 2006), both present in Chile (Klein and Waterhouse, 2000). Urban trees are the most vulnerable to $G$. brimblecombei, mainly because they are watered frecuently (Halbert et al., 2001).

In the countries where G. brimblecombei has been detected, it has been found in diverse species of the genus Eucalyptus. In Australia, E. brassina Blake, E. bridgesiana Baker, E. camaldulensis, E. camphora Baker, E. dealbata Cunn ex Schauer, E. mannifera Baker, E. nitens Deane \& Maiden, and E. tereticornis Smith have been mentioned as hosts (Brennan et al., 2001; Paine et al., 2006). In California, E. rudis Endl, E. tereticornis, and E. camaldulensis have been identified as highly susceptible hosts (Paine et al., 2006), and E. camaldulensis, E. blakelyi Maiden, E. nitens, E. dealbata, E. bridgesiana, E. brassina, E. mannifera, E. botryoides Sm., E. cladocalix Muell., E. cornuta Labill, E. globulus, E. deglupta Blume, E. grandis Hill, E. marginata Donn, E. punctata DC., E. rudis and E. robusta Smith are hosts in Mexico (Macías, 2001). In Brazil, G. brimblecombei was found also in a Eucalyptus $x$ urograndis hybrid (De Queiroz et al., 2003).

According to Ide et al. (2006), the most susceptible species of eucalypts would be E. camaldulensis and E. nitens; while E. globulus, E. grandis and $E$. viminalis Labill, would have low to medium susceptibility.
The large area planted with species of Eucalyptus (over 600 thousand ha; INFOR, 2009) susceptible of being affected by this insect in Chile, stresses the importance to study the susceptibility of one-year-old plants of this species to psyllid. Also, it is interesting to determine the duration of the development stages of the insect to know its biology and to support the integrated management of this pest.

\section{Materials and methods}

The study was conducted at the facilities of the "Servicio Agrícola y Ganadero, Región Metropolitana de Chile" (Agriculture and Livestock Service, Metropolitan Region, Chile), Commune of Estación Central, during March and April of 2004. This area has a mild arid Mediterranean Mesothermal Stenothermic climate, typical to the central valley and coast of Chile, with hot and dry summers, and cold winters, with temperature averages ranging from $4.4{ }^{\circ} \mathrm{C}$ in July to a maximum of $28.2^{\circ} \mathrm{C}$ in January, a period free of freezing of 231 days, an average of 11 freezes per year, an annual mean precipitation of $419 \mathrm{~mm}$, a water deficit of $997 \mathrm{~mm}$ and a dry period of eight months (Santibáñez and Uribe, 1993).

The average monthly temperatures in Quinta Normal, obtained at the National Civil Aeronautical Authority, Technical Aeronautical School, Quinta Normal, Santiago, Chile, during the study period in March and April 2004 were $20.73,20.19$, and $15.65^{\circ} \mathrm{C}$, respectively.

Plants of E. camaldulensis, E. globulus, and $E$. nitens, species of eucalypts among the most planted in Chile and potential hosts of G. brimblecombei were selected for the study. The first two were obtained from the Antumapu tree nursery of the University of Chile located in La Pintana, Santiago, and E. nitens from the MonteAguila Forestry and Agriculture Nursery in Los Ángeles (Bío Bío Region). The plants were transplanted from bags to pots containing $400 \mathrm{~mL}$ of disinfested plant litter soil. 
The psyllids were collected with nets and insect aspirators from an adult stand of E. camaldulensis severely infested in La Pirámide, Metropolitan Park of Santiago.

The growth of plants infested with G. brimblecombei in the field was studied from February thorugh April 2004, under two treatments by plant species, with and without insects (control), each one with 32 plants. All the plants were covered with a light cloth to avoid insects from escaping and to homogenize light and humidity conditions in all treatments, and also to keep insects out from controls. The infestation was done at two stages, first with 100 adult insects, and seven days later, adding other 60 individuals per plant to infest, to ensure establishment. Four measurements were performed, every 15 days, on random samples of eight plants (four infested and four controls) per species. The homogeneity of the plants was verified 15 days after the first infestation using fixed effect Anova.

The height $(\mathrm{cm})$, diameter at the base of the trunk $(\mathrm{mm})$ and foliar area $\left(\mathrm{mm}^{2}\right)$ were measured using a scanner, the LeafArea 1.3 software (University of Sheffield, 2003), and Adobe Photoshop 7.0. The results had a normal distribution and are presented as means $\pm \mathrm{SD}$. Fixed effect Anova $(\mathrm{P} \leq 0.05)$ was used to determine if the presence of the insect influences the decrease of height, diameter at trunk base, and foliar area of the plants at each evaluated period.

To determine the duration of the stages of development, one hundred $G$. brimblecombei adults (males and females) were collected at the Metropolitan Park. These insects were placed on one-year-old E. camaldulensis plants, which were covered with a light cloth, surrounded by burned oil and their pots placed on a dish with water to avoid predation by other insects, such as Argentine ants, Linepithema humile (Mayr) (Hymenoptera: Formicidae) and European earwigs, Forficula auricularia L. (Dermaptera: Forficulidae). Their metamorphosis was observed periodically, from February through April 2004.

\section{Results}

Evaluation of growth losses of Eucalyptus plants

Fifteen days after the first infestation, the tests for homogeneity on the three species of eucalypts for the three variables measured, height, diameter at trunk base, and foliar area, did not find significant differences between the treatments with insects and the controls, which allowed continuing the study with the methodology proposed.

As G. brimblecombei could only develop on plants of E. camaldulensis and not in the other species (E. nitens and E. globulus), evaluations were performed only on the first species.

The plants infested with adults of $G$. brimblecombei presented numerically, but not statistically inferior means in development of height, diameter at trunk base, and foliar area in comparison with the control plants after two months (Table 1).

Table 1. Changes in height, diameter at trunk base, and foliar area caused by two-month infestation with adults of Glycaspis brimblecombei on one-yr-old plants of Eucalyptus camaldulensis, in Santiago, Chile (2004).

\begin{tabular}{lllc}
\hline & \multicolumn{2}{c}{ Ratio $^{1}$ (mean \pm SD) } & \\
\cline { 2 - 3 } Variables & $\begin{array}{l}\text { Control } \\
\text { plants }\end{array}$ & $\begin{array}{l}\text { Infested } \\
\text { plants }\end{array}$ & $\begin{array}{c}\% \\
\text { reduction }\end{array}$ \\
\hline $\begin{array}{l}\text { Height } \\
(\mathrm{cm})\end{array}$ & $1.07 \pm 0.26 \mathrm{a}$ & $1.01 \pm 0.21 \mathrm{a}$ & 5.3 \\
$\begin{array}{l}\text { Diameter } \\
\text { at trunk } \\
\text { base }(\mathrm{mm})\end{array}$ & $1.11 \pm 0.17 \mathrm{a}$ & $1.18 \pm 0.27 \mathrm{a}$ & 0.6 \\
$\begin{array}{l}\text { Foliar area } \\
\left(\mathrm{mm}^{2}\right)\end{array}$ & $1.39 \pm 0.45 \mathrm{a}$ & $1.36 \pm 0.46 \mathrm{a}$ & 2.3 \\
\hline
\end{tabular}

${ }^{1}$ The ratio is the average quotient of the final and initial measurements. The same letter on each row indicates absence of significant statistical differences $(\mathrm{P} \leq 0.05)$.

Heigth. Slight numerical differences in average heights of E. camaldulensis appear in Figure $1 \mathrm{~A}$ at day 15 from first infestation. However, 
these were not significant between plants with and without insects. Similar results were observed at the following evaluations, with height means slightly smaller in the infested plants, but with no statistical differences. Thus, $G$. brimblecombei did not affect height development of plants.
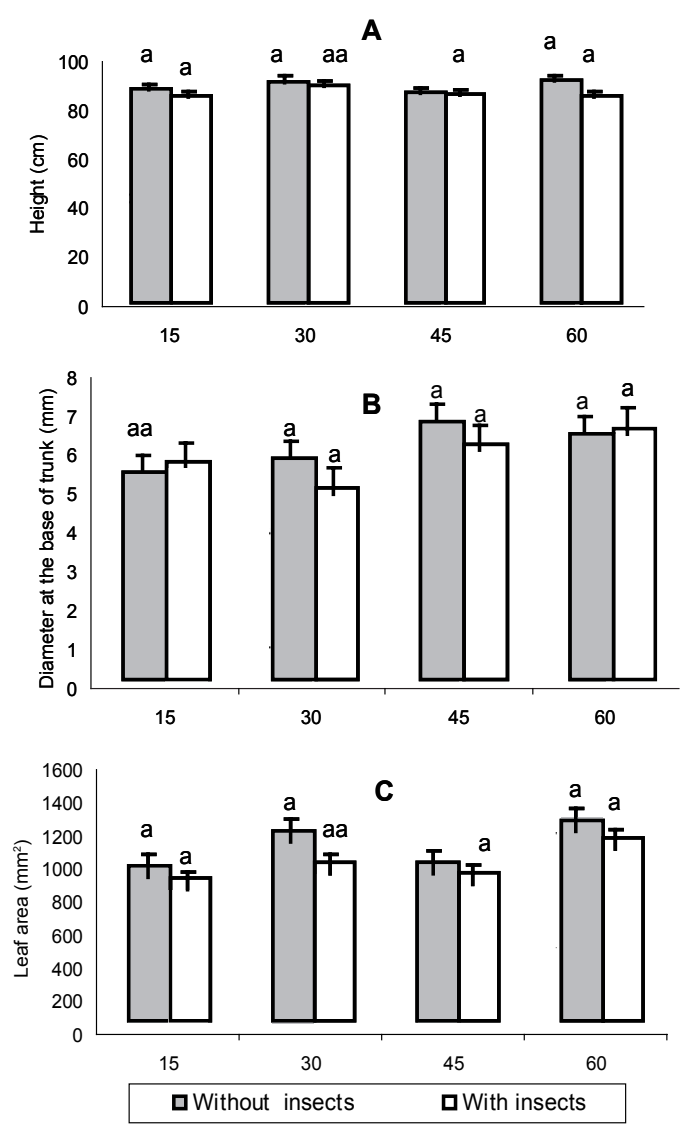

Figure 1. Differences in development (average \pm SD) of one-yr-old plants of Eucalyptus camaldulensis with and without Glycaspis brimblecombei, on days after infestation in Santiago, Chile (2004). A: Heigth (cm). B: Diameter at trunk base $(\mathrm{mm})$. C: Leaf area $\left(\mathrm{mm}^{2}\right)$. The same letter on each evaluation indicates absence of significant statistical differences $(\mathrm{P} \leq 0.05)$.

Diameter at trunk base. Although numerical differences were observed between the means of diameter at trunk base of E. camaldulensis, no significant statistical differences occurred in the evaluations, thus the plants did not present a change in development of diameter at trunk base attributed to G. brimblecombei (Figure 1B).
Foliar area. As with the other parameters in the evaluations, numerical but not statistical differences occurred between the means of foliar area of plants infested by E. camaldulensis and those of the control that could be attributed to G. brimblecombei.

Duration of the development stages of $G$. brimblecombei

The observations allowed evaluating two complete generations of $G$. brimblecombei from February through April 2004. The first generation (February-March) completed its cycle, from appearance of the first egg through the death of the last adult in approximately 30 days, while the second (March- April 2004) required near 36 days. The egg, nymph and adult stages of the first and second generations of G. brimblecombei lasted nine, eighteen, and five days, and nine, twenty-three, and six days, respectively.

\section{Discussion}

The establishment of G. brimblecombei only on E. camaldulensis could be explained by the greater degree of susceptibility of this eucalypt species to this psyllid. Brennan et al. (2001) in California and Ide et al. (2006) in Chile identified E. camaldulensis among the most vulnerable plant species. In a study with 22 species in Sao Paulo (Brazil), Wilcken et al. (2003) classified E. camaldulensis, together with E. tereticornis and E. urophylla, as very susceptible species to G. brimblecombei.

On E. globulus and E. nitens, the psyllid did not get established. According to Floyd et al. (1994) and Floyd and Raymond (1998), species with foliar dimorphism like E. globulus y E. nitens have different chemical composition between the young and mature leaves, having chemicals with some degrees of toxicity. This agrees with Brennan and Weinbaum (2001), who have found a greater resistance to egg laying by $G$. brimblecombei on young leaves of E. globulus. 
This situation has not been studied for $E$. nitens, but the foliar dimorphism in this species would explain in part the absence of the insect. The chemical composition of young leaves of these plant species would inhibit the establishment and ensuing reproduction of the psyllid.

According to Brennan et al. (1999, 2001), Garrison (2001), and Paine et al. (2006), among others, the development of natural populations of G. brimblecombei is explosive, and causes in a short time defoliation and even death of the plants affected. However, under an induced infestation in our study, the damage was not at the level expected. In this way, although lesser means in height, diameter at trunk base, and foliar area in the plants of Eucalyptus infested with the psyllid occurred, compared to plants not infested, these differences were not significant, due in part probably to the low establishment achieved by the insect.

Brennan et al. (1999), Nagamine and Heu (2001), Macías (2001), Garrison (2001), Paine et al. (2006), and De Queiroz et al. (2003) coincide in stating that G. brimblecombei causes losses in growth of diverse species of eucalypts, and even death. However, no such losses were detected that could be attributed to the insect in any of the species evaluated. It is worth mentioning that our results come from one-year-old plants, and not adult specimens strongly infested, on which infestation levels are very high. Probably, a larger exposure time to the pest may cause greater effects on growth and survival of plants, as indicated by Floyd and Foley (2001).

The small rates of reduction of foliar area in the species studied may be related to the need of the adults to feed and develop only on the tree where they emerged. Specifically, the adults may have not adapted completely to the foliage of E. globulus and E. nitens due to their particular chemical composition, as implied by Floyd and Foley (2001).

We recommend making a more detailed and longer duration study in the field, where the ef- fects of the psyllid on growth may be observed both on young and adult plants.

With respect to the duration of the stages of development of G. brimblecombei, the slower one of the second generation is expected to occur under less favorable conditions, as those taking place in Chile at the end of summer. During the evaluation period, the temperature records, one of the most relevant variables for insect development, revealed a downward trend.

In Australia, its native ground, G. brimblecombei presents two to four generations. Lifespan from egg stage to adulthood varies from several weeks with warm weather to several months when temperatures are colder (Garrison, 2001).

Only E. camaldulensis was susceptible to an induced infestation by $G$. brimblecombei on oneyear-old plants, while E. nitens and E. globulus did not present susceptibility to the insect, as no specimens of the insect at any stage of development were found on them. Possibly, the foliar dimorphism of these plant species, together with their different chemical composition, deters establishment on young leaves. Plants of $E$. camaldulensis infested with adults of G. brimblecombei had small and not significant reductions in growth, diameter at trunk base, and foliar area compared with the control plants after two months. At the Santiago bioclimatic area, G. brimblecombei presented two generations, lasting 30 and 36 days, from February through April.

\section{Acknowledgments}

The authors thank the "Programa de Protección Fitosanitaria del Servicio Agrícola y Ganadero, Región Metropolitana de Chile" (Plant Protection Program, Agriculture and Cattle Service, Metropolitan Region of Chile), by financing this research. 


\title{
Resumen
}

\begin{abstract}
A. Huerta, M. Faúndez y J. E. Araya. 2010. Susceptibilidad de Eucalyptus spp. a una infestación inducida del psílido de los eucaliptos rojos Glycaspis brimblecombei Moore (Hemiptera: Psyllidae) en Santiago, Chile. Cien. Inv. Agr. 37(2):27-33. Con el fin de conocer la susceptibilidad de especies de eucalipto importantes en Chile a Glycaspis brimblecombei Moore (Hemiptera: Psyllidae), insecto que se detectó sobre Eucalyptus camaldulensis Dehn. en 2002 en Santiago, y que causa defoliación en los árboles afectados, y su muerte en infestaciones severas, en 2004 se evaluó en el campo una infestación inducida sobre plantas de un año de $E$. camaldulensis, E. nitens Deane \& Maiden y E. globulus Labill. Las pérdidas de desarrollo de las plantas infestadas se compararon con testigos no infestados, mediante muestreos destructivos a los 15, 30, 45 y 60 días. Se hicieron también observaciones de la duración de los estados de desarrollo del insecto durante dos generaciones. La única especie susceptible al psílido fue $E$. camaldulensis, mientras que en E. nitens y E. globulus el insecto no se desarrolló. Las plantas de E. camaldulensis infestadas con adultos de G. brimblecombei tuvieron reducciones leves, pero no significativas, en el desarrollo en altura, diámetro a la altura del cuello y área foliar en comparación con las plantas testigo después de dos meses. En la zona bioclimática de Santiago, este insecto completó la primera generación en 30 días (febrero-marzo) y la segunda en 36 días (marzo-abril).
\end{abstract}

Palabras clave: Eucalyptus camaldulensis, Eucalyptus globulus, Eucalyptus nitens, Glycaspis brimblecombei, psílido de los eucaliptos rojos.

\section{References}

Beéche, M. 1999. Programa de detección y control del gorgojo del eucalipto en Chile, Gonipterus scutellatus (Gyll.) (Coleoptera: Curculionidae). XXI Congreso Nacional de Entomología, Chile, Arica (Abstract). p. 33-34.

Brennan, E., G. Gill, F. Hrusa, and S. Weinbaum. 1999. First record of Glycaspis brimblecombei Moore (Homoptera: Psyllidae) in North America: initial observations and predator associations of a potentially serious new pest of Eucalyptus in California. Pan Pacific Entomologist 75(1): 15-57.

Brennan, E., F. Hrusa, S. Weinbaum, and W. Levison. 2001. Resistance of eucalyptus species to Glycaspis brimblecombei (Homoptera: Psillidae) in the San Francisco Bay Area. Pan Pacific Entomologist 77(14): 249-253.

Brennan, E., and S. Weinbaum. 2001. Effect of epicuticular wax on adhesion of psyllids to glaucous juvenile and glossy adult leaves of Eucalyptus globulus Labillardiere. Australian Journal of Entomology 40: 270-277.
De Queiroz, D., A. Menezes, H. Damin, A. Jurado, and R. Marcassi. 2003. O psilídeo-de- concha (Glycaspis brimblecombei) em eucalipto. Comunicado Técnico (Brasil) 150: 1-3.

Floyd, R., R. Farrow, and F. Neumann. 1994. Inter and intra-provenance variation in resistance of red gum foliage to insect feeding. Australian Forestry 57: 45-58.

Floyd, R.B., and W.J. Foley. 2001. Identifying pest resistant eucalyptus using near-infrared spectroscopy. RIRDC Publication 01/112, Canberra, Australia. $110 \mathrm{pp}$.

Floyd, R., and C. Raymond. 1998. Insect resistance of Eucalyptus species in Australia. Proceedings International Forest Insect Workshop. Chile, IX Región, Pucón. p. 249-257.

Garrison, R. 2001. New agricultural pest for southern California. Red gum lerp psyllid, Glycaspis brimblecombei. Los Angeles County Agricultural Commissioner's Office. Web accessed: 12 Aug. 2009 Available online at: http://acwm.co.la. ca.us/pdf/Lerp.pdf

Halbert, S., R. Gill, and J. Nisson. 2001. Two Eucalyptus psyllids new to Florida (Homoptera: Psyllidae). Department of Agriculture \& Consumer 
Services, Division of Plant Industry. Entomology Circular 407(July/Aug.): 1-2.

Ide, S., C. Muñoz, M. Beéche, J. Mondaca, L. Jaques, P. González, and C. Goycoolea. 2006. Detección y control biológico de Glycaspis brimblecombei Moore (Hemiptera: Psyllidae). Servicio Agrícola y Ganadero, Ministerio de Agricultura, Santiago, Chile. 32 pp.

Instituto Forestal (INFOR). 2009. Superficie de plantaciones forestales 2007. Web accessed: 12 Aug. 2009. Available online at: http://www. infor.cl/estadisticas_mercado/super_plantaciones_forest.htKlein, K.C., and D.F. Waterhouse. 2000. The distribution and importance of arthropods associated with agriculture and forestry in Chile. ACIAR Monograph (Chile) 68. $231 \mathrm{pp}$.

Macías, J. 2001. Plagas forestales neotropicales. Manejo Integrado de Plagas (Costa Rica) 62: 9091.

Meza, P., and A. Baldini. 2001. Dos nuevos psílidos en Chile Ctenarytaina eucalypti y Blastopsylla occidentalis. Corporación Nacional Forestal (Chile). Documento Técnico 9: 1-34.

Nagamine, W., and R. Heu. 2001. Red gum lerp psyllid. Department of Agriculture, State of Hawaii. New Pest Advisory 2: 1-2.
Paine, T.D., S.H. Dreistadt, R.W. Garrison, and R.J. Gill. 2006. Eucalyptus red gum lerp psyllid. University of California, Agriculture and Natural Resources, Statewide IPM Program, Davis, US, Pest Notes Publication 7460: 1-4.

Poisson, M., and A. Sandoval. 1998. Revisión de insectos y enfermedades asociadas al género Eucalyptus en Chile. Informe Misión USDA-APHIS. Servicio Agrícola y Ganadero, Santiago, Chile. 43 pp.

Sandoval, A., and S. Rothmann. 2002. Detección del psílido de los eucaliptos rojos, Glycaspis brimblecombei Moore 1964, en Chile (Homoptera: Psyllidae). XXIV Congreso Nacional de Entomología. Santiago, Chile (Abstract).

Santibáñez, F., and J. Uribe. 1993. Atlas agroclimático de Chile: Regiones IV-IX. Universidad de Chile. Santiago, Chile. 64 pp.

University of Sheffield. 2003. Programme LeafArea Measurement Version 1.3. Web accessed: 20 Oct. 2008. Available online at: http://www.shef. ac.uk/ nvocpe/ucpe/leafarea.html

Wilcken, C., E. Cuoto, C. Orlato, P.J. Ferreira-Filho, and D.C. Firmino. 2003. Ocorrência de psilídeode-concha (Glycaspis brimblecombei) (Hemiptera: Psyllidae) em florestas de Eucalipto no Brasil. Piracicaba, Brasil. Instituto de Pesquisas e Estudos Florestais. Circular Técnica 201: 1-11. 
